NBER WORKING PAPER SERIES

\title{
ECONOMICS AND POLITICS OF RICE \\ POLICY IN JAPAN: A PERSPECTIVE \\ ON THE URUGUAY ROUND
}

Yujiro Hayami

Yoshihisa Godo

Working Paper 5341

\author{
NATIONAL BUREAU OF ECONOMIC RESEARCH \\ 1050 Massachusetts Avenue \\ Cambridge, MA 02138 \\ November 1995
}

This paper was prepared for the Sixth Annual NBER East Asian Seminar on Economics, held June 15-17, 1995 in Seoul, and is part of NBER's research program in International Trade and Investment. Any opinions expressed are those of the authors and not those of the National Bureau of Economic Research.

(c) 1995 by Yujiro Hayami and Yoshihisa Godo. All rights reserved. Short sections of text, not to exceed two paragraphs, may be quoted without explicit permission provided that full credit, including $\odot$ notice, is given to the source. 


\title{
ECONOMICS AND POLITICS OF RICE \\ POLICY IN JAPAN: A PERSPECTIVE \\ ON THE URUGUAY ROUND
}

\begin{abstract}
This paper reviews the recent problems of the opening of Japan's rice market and evaluates the Japanese government's rice policy from both an economic and political viewpoint. The Japanese government made strenuous resistance to the opening of Japan's rice market during the negotiations on agricultural trade at the GATT Uruguay Round. Eventually Japan's rice was made exempt from tariffication by compensating in the form of increased "minimum access" import quotas. However, the tariffication rule of the final agreement guarantees that importing countries can impose considerably high tariffs. Thus, the volume of Japan's rice imports could be decreased if the Japanese government accepted the tariffication agreement. In retrospect the decisions made by the Japanese government have effectively protected the vested interests of the domestic rice distribution system, while hindering the structural improvement of the Japanese rice industry.
\end{abstract}

Yujiro Hayami

SIPEB

Aoyama Gakuin University

4-4-25 Shibuya

Shibuya-ku, Tokyo 150

JAPAN
Yoshihisa Godo

Department of Economics

Meiji Gakuin University

1-2-37 Shirokane-dai

Minato-ku, Tokyo 108

JAPAN 


\section{Introduction}

Throughout the seven-year duration of the GATT Uruguay Round (UR), agricultural negotiation continued to be a major stumbling block. Because of the domestic resistance in these negotiations, the Japanese and Korean government were unable to play a sufficiently positive role in the Round despite the large benefits that they are expected to receive from the successful conclusion of the Round 1 . Their dilemma was clearly demonstrated by their evasion of 'tariffication' of rice effectively violating of the principles of GATT/WTO.

The tariffication by which all existing non-tariff barriers are converted into bound duties is a key element regarding market access in the Agreement on Agriculture embodied in the Final Act of the Uruguay Round. Yet, Japan managed to make rice exempt from the tariffication in a six-year grace period from 1995 to 2000, by giving compensation in the form of increased "minimum access" import quotas, from 4 percent of its domestic rice consumption in 1995 to 8 percent by 2000, while the minimum access obligation under tariffication is graduated only from 3 to 5 percent within the six-year period. Likewise, Korea agreed to increase minimum access imports from 1 percent of the base-period domestic consumption to 4 percent during the 19952000 period with a ten-year postponement of rice market tariffication. Indeed, this experience in Japan and Korea demonstrated that rice in East Asia is not simply an economic good but is considered to be a cultural heritage, therefore, is easily influenced by political forces.

The question to be addressed in this paper is what political forces oppose the acceptance of the general agreements on Agriculture of the UR. We will try to find an answer mainly in reference to the case of rice in Japan but the major substance of this study is expected to apply to Korea, as well. The answer to this question will become a basis for projection on agricultural policies and trade regimes in Northeast Asia for a decade following the UR.

2. A Perspective on the Uruguay Round Agricultural Negotiations

In order to understand the unique response of Japan (and Korea) to the UR agricultural negotiations, it is useful to compare its position in regard to agricultural protection visa vis EU and the United States in Table 1. 


\subsection{Stylized facts of agricultural protection}

The first column in table 1 compares the levels of agricultural protection in terms of the ratio of producer subsidy equivalent (PSE) to total agricultural output value for 1991-93. PSE measures the increase in producers' income owing to all the protective policies including both border protection and domestic subsidy payments. When using this measure, the agricultural protection of Japan is very high with the PSE ratio amounting to about 70 percent, as compared with about 50 percent in EU, 20 percent in the United States and 10 percent in Australia. Especially high is the protection for rice with PSE amounting to nearly 90 percent of output value. Note that these ratios use agricultural output values as denominators. If we assume value added from agriculture to be 60 percent of output value, Japan's PSE for 1991-93 amounted to 115 percent of agricultural GDP, implying that the national income of Japan would have increased by 15 percent with the elimination of the agricultural sector $\underline{2}$.

In table 1, strong inverse correlation can be observed between the PSE ratio in column (1) and the grain self-efficient ratios in columns (3) and (4). This inverse association seems to reflect the general tendency that countries with a lower comparative advantage in agriculture undertake higher protection. It is noteworthy, however, that both the United States and Australia with an obviously high comparative advantage in agriculture are engaging in agricultural protection to a significant degree. Again, assuming the value added to be 60 percent of output value, the ratio of PSE to agricultural GDP is nearly 40 percent in the United States and 15 percent even in Australia. Thus, Japan's high protection on agriculture is but one example of the stylized facts that (a) developed countries exercise high protection on agriculture and (b) the degree of protection is higher for countries with a lower comparative advantage in agriculture 3 .

\subsection{The common interest of EU and the United States}

Another important observation in table 1 is the inverse correlation between the ratio of (negative) consumer subsidy equivalent (-CSE) to PSE in column (2) and the grain self-sufficiency ratio in columns (3) and (4). The income support for farmers as measured by PSE is considered to consist of income transfers from both consumers and taxpayers. Border protection increases the purchase price of agricultural commodities, and thus consumers experience a decrease in the purchasing 
power or real income. The CSE is therefore a measure how consumers support protection via their income reduction. On the other hand, the transfer from taxpayers takes the form of government's subsidy payments. Thus, the ratio of (-CSE) to PSE measures how much of agricultural protection is based on the expense of consumers relative to that of the government budget.

The high ratio of (-CSE) for Japan and the low ratios for the United States and Australia reflect the fact that, in a major food importing country like Japan, the high protection rate can be achieved mainly by border protection with relatively little pressure on the government budget, while major food exporters must rely on the treasury if they want to support the income of farmers. In this perspective, the critically important factor underlying the adoption of agricultural policy reform as an issue at the UR could be identified as the change in position of EU from a net grain importer in the 1970 s to a net exporter in the 1980s, as shown in columns (3) and (4).

Since the formation of EC in 1957 until the 1970s, EU had been a worldleading importer of grains and many other agricultural commodities. As long as the import margins remaind large, EU could protect farmers at a target level mainly by means of the variable levies that produce revenue instead of cost to the EU government. However, as domestic agricultural production grew larger under heavy protection of the Common Agricultural Policy (CAP), imports progressively reduced resulting in a growing shortage of variable levy revenue relative to the need of maintaining the CAP program. This became more acute in the $1980 \mathrm{~s}$, when EU became a net exporter. Because the surplus commodities above domestic consumption were created by the heavy protection, they could not find commercial outlets in the international market. Inadvertently through export subsidies EU began overseas dumping activities. Under the pressure of surplus products the budget cost of CAP loomed large and became politically intolerable, especially in the mid-1980s when the world food market was dampened.

Thus was the reasoning why EU and the United States agreed to put agricultural policy reform in the agenda of UR negotiations. Namely, when EU became a net exporter, it went on board the same boat as the United States. It was no longer possible for them to finance the cost of agricultural protection at the expense of consumers. Given the high political cost of raising taxes, it became an absolute necessity to reduce agricultural protection or, at least, to stop further growth of protection. If they had not shared this problem, it is difficult to envisage that the UR negotiations on agricultural policy reform would have ever been undertaken. 
Surplus production due to excessive protection was the basic cause of looming budget costs in exporting countries. Thus the UR agricultural negotiations could not be limited to the issue of trade rules and market access but had to be expanded to cover domestic agricultural policy and export subsidies.

In this perspective, the CAP reform in 1992 under the lead of EC Commissioner Ray McSharry would have had to have been undertaken even in the absence of UR negotiations, although there is little doubt that the reform was facilitated by the UR 4 . The CAP reform was essentially a shift from the traditional EC policy of supporting farm prices by means of border protection, to the protection structure similar to that of the U.S. consisting of acreage control and subsidy paymenys to farmers. This policy shift has already demonstrated its effect in curbing farm production so that export surplus are likely to decrease in the future.

\subsection{The unique position of Japan}

It is important to recognize that Japan has not been in the same situation as $\mathrm{EU}$ and the U.S.. As indicated in table 1, the import margin of grains has been widening and the cost of agricultural protection has been almost completely covered by consumers. With increasing affluence, consumers are becoming more tolerant of high food prices, while most of them do not realize how high the prices actually are. Their tolerance is especially high for rice, mainly because it has turned out to be an inferior good, whereby demand shrinks in response to increases in the income level. As the share of rice in consumers' expenditure is now less than 2 percent (as compared with about 3 percent for vegetables), its effect on the cost of living has become insignificant. In result, both business employers and labor unions are not concerned about the price of rice. Thus, the countervailing power against agricultural protection has disappeared from Japanese society $\underline{5}$.

Consumer tolerance on agricultural protection is common among affluent societies. What makes Japan unique relative to $\mathrm{EU}$ and the United States is the relative absence of countervailing pressure from the Ministry of the Finance; this is because Japan as a major food importer is able to charge the consumers for the costs of protection. Under this unique condition Japan has had little political incentive to promote agricultural policy reform in the arena of the UR. While the expected benefit from a freer trade regime is obviously very large, the benefit would be distributed widely but thinly among consumers, business concerns and organized laborers. No interest group has sufficient incentive to exercise countervailing power 
against the strong political pressure of the farm bloc. Thus, it appears reasonable to hypothesize that Japan remained very passive in the UR agricultural negotiations and tried to evade as much as possible any agreement which may evoke the anger of the farm bloc, partly because the farm bloc is politically very powerful as it is disproportionately represented in the national diet, but more importantly because no other political bloc dared to undertake the counter motion of promoting the UR agricultural negotiations.

Under such conditions, Japanese negotiators, who first tried to take the lead in advancing the UR when it began in 1986, failed to make active contributions as the negotiations dragged on. Instead, they were forced to adopt the usual Japanese stance of waiting for other nations to work out a solution and then accepting the agreement to the minimum possible concessions.

\section{Evasion of Rice Tarifficaton}

Now, the relevant question to ask is why the rice market tariffication was so strongly opposed by the Japanese government. Would the tariffication destroy Japanese agriculture and result in an unbearable burden on our farmers as well as the demise of an agricultural heritage? In fact this scenario seems unlikely from any calculations based on sound knowledge.

\subsection{Possible impact of tariffication}

The tariffication in the UR Agreement is to replace in 1995 all the nontariff barriers by tariffs at rates equivalent to the differences between the domestic (wholesale) and the international (import cif) prices and, then, to reduce the tariff rates by 36 percent on the average with a minimum of 15 percent for individual commodities within the 6-year period from 1995 to 2000 . How would this scheme affect our rice farmers? It should be more than reasonable to assume that, upon the acceptance of this plan, the Japanese government would seek approval for the application of the minimum 15-percent tariff reduction on rice. This implies that an average reduction in the rice tariff rates per year would be only 2.7 percent. The effect of the tariff reduction to lower the domestic price of rice in the following 6 years can be calculated as follows:

The average rate of reduction in the tariff rate $(a \times 100 \%)$ for reducing the tariff rate by 15 percent within the 6 -year period is calculated as 2.7 percent ( $a=$ 
0.027 ) per year from following relation:

$$
(1-a)^{6}=0.85
$$

If rice is allowed to be imported freely from abroad at the tariff rate of $t \times 100$ percent, the relation between the domestic price $(P)$ and the import cif price $(R)$ of rice is established as

$$
P=R(1+t)
$$

If $t$ is reduced by $a \times 100$ percent, the new domestic price $(p)$ becomes

$$
P=R\{1+t(1-a)\} \text {. }
$$

The rate of reduction in the domestic price ( $c$ ) corresponding to this tariff reduction is calculated as

$$
c=\frac{\left(p-p^{\prime}\right)}{p}=\frac{a t}{(1+t)}
$$

In general, for a given value of $a$, the larger is the value of $t$, the larger is the value of $c$. However, even if the initial tariff rate is set at 700 percent ( $t$ $=7$ ) based on a rather high estimate of the tariff equivalent for rice in Japan by the US International Trade Comission (1990) and this rate is cut by 15 percent in 6 years or 2.7 percent $(a=0.027)$ per year, the domestic price is expected to fall only by 2.3 percent per year. Even if an unrealistically high rate of 1,200 percent $(t=12)$ is assumed for the tariff equivalent, the rate of corresponding reduction in the domestic price is just 2.5 percent. On the other hand, if the tariff equivalent is determined as 300 percent $(t=3$ ) according to the estimate by the Forum for Policy Innovation (1990), which seems to be a more reasonable estimate as discussed in Appendix $A$, the rate of decline in the domestic price corresponding to a 2.7 percent reduction in the tariff rate, is only 2.0 percent per year.

This means that, if rice farmers in Japan would be able to reduce their production costs at the speed of 2.5 percent per year, they would incur no damage from the UR tariffication. Considering the fact that the producer price of rice under the government control was lowered on the average by 2.5 percent per year for 1986- 
1991, it is reasonable to expect that Japanese farmers would be able to withstand the UR tariffication.

It must be noted that the above calculation is based on the assumption of " clean" tariffication in which the initial tariff rate is set exactly equal to the domestic-border price difference. In fact, however, because it is technically difficult to determine the relevant prices between the domestic and international market, it is relatively easy to set the initial tariff rate significantly higher than necessary to prevent imports occurring, as the EU examples seem to demonstrate-

\subsection{The experience of beef tariffication}

Tarrification in itself would not cause imports to grow. How high the initial tariff rates are and the speed of their reduction determine how well imports do. This is clear from the previous experience of tariffications on beef.

A quota system for imported beef was replaced by tariffication in 1991 through the U.S.-Japan bilateral negotiation?. Has this resulted in rapid growth of beef imports? The answer is no. As shown in table 2, while beef imports grew at an average annual rate of 20.4 percent over the 5 years that quotas were in effect, their annual growth has averaged only 12.5 percent over the four years since the shift to tariffication. Meanwhile, annual domestic production remained almost constant at about 400 thousand tons ${ }^{8}$. If the level of initial tariffs and the speed of tariff cuts are set appropriately, it can be argued that tariffication can be more effective in curbing imports as compared to setting quantitative import restrictions.

In the case of beef, the tariff rate was reduced by about 30 percent within two years from 1991 to 1993, which was six times faster than the minimum allowable rate of reduction of 15 percent for six years (equivalent to 5 percent for two years) in the UR Agreement. If the tariff rate reduction for beef were as small as 5 percent, the tariff rate in 1993 should have been 66 instead of the actual level of 50 percent. If so, judging from the decrease in beef imports in the first years of tariffication under the tariff rate of 70 percent, it is unlikely that any significant increase in beef import would have occurred since tariffication, if the conditions of tariffication applied to beef were the same as those of the UR tariffication applicable to rice. 


\subsection{Effectiveness of safeguards}

Often cited as opposition against tariffication was the danger of rice imports increasing due to sharp declines in border prices, which might arise from such factors as foreign exchange rate appreciation, changes in overseas supply conditions, and dumping by exporters.

However, the UR Agreement includes strong safeguard measures. One is the " special safeguards" that allow the importer to increase the tariff rate corresponding to the decline in border price or import quantity increase. Another could be the use of a specific duty instead of an ad valorem tariff. The safeguard power will be extremely strong for a commodity like rice in Japan characterized by a large domestic-border price difference, if the price-triggered safeguard and the specific duty are combined. This is illustrated in table 3, in which as an extreme case the border price declines from 50 yen per $\mathrm{kg}$ to only 10 yen per $\mathrm{kg}$, under the assumption of an initial tariff rate of 300 percent.

Initially, the domestic price is assumed to be 200 yen per $\mathrm{kg}$ by adding a 300 -percent tariff ( 150 yen per $\mathrm{kg}$ ) to the border price of 50 yen per $\mathrm{kg}$. If the ad valorem tariff is applied, corresponding to the reduction in the border price from 50 to 10 yen per $\mathrm{kg}$, the domestic price will decline sharply from 200 to 40 yen per $\mathrm{kg}$. Special safeguards will be of little help in this situation. However, if the specific duty is fixed at 150 yen per $\mathrm{kg}$, the domestic price will decrease only slightly from 200 to 160 yen despite the border price decrease from 50 to 10 yen. If the pricetrigger safeguard is applied in addition, the domestic price of imported rice will decrease only to 176 yen per $\mathrm{kg}$. If the quantity-trigger safeguard is applied instead, the domestic price of imported rice will become higher than the prior price level of domestic rice, with no possibility of a further increase in rice imports.

\subsection{Vested interests against tariffication}

Thus, if the initial tariff rate is appropriately set to cover the domesticborder price difference and the safeguard measures are adequately combined, rice imports under tariffication would have been kept much lower than the level of imports under increased minimum access. This is an easy conclusion to draw, about which capable government officials in Japan could hardly be ignorant. If so, why did Japan endeavor to make rice an exception to the general principle of the UR Agreement?

The answer appears to be because tariffication threatens to damage the vested 
interests that are protected by the nation's food control system-9. In particular, it would eventually destroy the monopolistic control over rice marketing by the Food Agency and agricultural cooperatives. Under the Food Control Law all the rice is supposed to be collected by village agricultural cooperatives, which is either sold to the Food Agency ( the so-called "government rice" channel) or sold to the licensed wholesalers (the so-called "voluntary rice" channel) for further distribution to the retail level, even though some rice is, in practice, distributed illegally through the black market ( so-called "free rice") (See figure 1). In order to establish rice selling rights through the legal channels, rice farmers have to divert a certain portion of their paddyfield area away from rice production; this acreage control program was created to maintain domestic rice prices far above the market equilibrium level under autarky. This system has been the major source of institutional rent for both agricultural cooperatives and the Food Agency. The rent partly goes to farmers through price increases. But it mainly goes to the Food Agency and the agricultural cooperatives in order to continually expand the size of these institutes. It should be noted that almost all farmers are members of agrucultural co-operatives, yet there are cases where the benefits received by the individuals differ to the benefits received by the co-operatives. Agricultural co-operatives through their strong political force oppose the tariffication although certain members within the coopratives have differnig opinions on the issue.

The tariffication implies the drilling of a hole in this food control system by which all rice is controlled by the Food Agency. It is a step toward the marketoriented reform of the rice distribution system. In contrast, the minimum access import quota system in which rice imports are all controlled by the Food Agency presents no opportunity for such reform. It is considerable that windfall profits from the mark-up sale of minimum-access foreign rice at the high domestic price will be used in order to strengthen the present food control system.

Under the present system, rice production in Japan is controlled by paying farmers subsidies to reduce the amount of farmland dedicated to growing the crop. This helps maintain high prices that far exceed the levels that would prevail under free-market conditions. Also, acreage control is allocated almost equally among farmers, with the effect of preventing the concentration of rice production among more efficient growers. This is a major obstacle in exploiting in the scale economies that have emerged in agricultural industry since the large-scale progress in mechanization induced by sharp increases in the wage rates in the 1970s. And because rice prices and marketing systems are inflexible, this prevents farmers from making 
the most of their entrepreneurial abilities $\stackrel{10}{ }$. One way of enhancing these abilities would be the removal of government controls on rice marketing, along with the promotion of cost reduction by gradual reductions of domestic prices. By evading tariffication while rice prices are kept high by reducing rice acreage at a rate equivalent to the increase in minimum-access imports, perhaps the incentive for reforms will weaken.

Indeed, the maintenance of high domestic prices by means of acreage control in response to shrinking domestic demand has been the continual policy mix in Japan and consistantly hindered the growth of Japanese agriculture. This policy mix is likely to continue in an accentuated manner with increased minimum-access import. If the evasion of tariffication is harmful rather than beneficial to agriculture, one could consider that if it has been adopted because it protects the vested interests of the Food Agency and agricultural cooperatives.

In order to support the arguments above we will try to show, by means of a simple simulation analysis, the likely course of the rice sector after the Uruguay Round under the traditional policy mix in contrast with possible other courses under alternative policy mixes.

4. The Political-Economy Dynamics of the Rice Market

As a background to the simulation analysis, this section tries to identify the goals and means of traditional rice policy in Japan in terms of its consequences.

\subsection{Policy-induced cycles 11}

The revealed objective of Japan's rice policy since the 1960s when Japan joined the group of high-income countries appears to be the support of domestic producer prices within the constraints of the government budget. Various policy means designed to achieve this goal, when interacted with market forces, have created major fluctuations in the rice market as shown in figure 2.

Government efforts to increase the producer price of rice was intensified especially in the early 1960s when high economic growth (Kodo Keizai Seicho) tended to widen the rural-urban income disparity. Because all the rice was then procured by the Food Agency through agricultural cooperatives, the producer price could be increased by raising the government-purchase price. Corresponding rapid rises in the purchase price, created a deficit for the Food Agency because the government-sale 
price increase had a timelag of a few years.

However, the extremely rapid increase in the government deficit during the 1960 s resulted more from the response of the market to the increased price than from the increase in the negative government-marketing margin. The increased producer price stimulated production and market supply. From 1960 to 1968, total rice output increased by 14 percent from 12.5 to $14.2 \mathrm{million}$ tons, while total sales to the Food Agency rose faster by as much as 67 percent from 6.0 to $10.0 \mathrm{million}$ tons. Given the negative marketing margin, the deficit from the food control program increased proportionally with the increase in rice procurement by the Food Agency.

More serious was the accumulating surplus in government storage. During the 1960s, rice became an inferior good corresponding to per capita income rises; average per capita rice consumption per year declined steadily from a peak of 118 kilograms in 1962 to $100 \mathrm{kilograms}$ in 1970. In addition to negative income elasticity of demand, the increased price should have also contributed to the decline in rice consumption to some extent. With the bumper crop in 1967, the excess supply of rice became especially evident in the form of a sharp increase in the quantities of old rice in the government stocks.

The multiplying financial burden arising from excess supply forced the government to introduce three simultaneous measures in 1968: (a) restraint on the price of rice, (b) acreage control, and (c) disposal of surplus rice $\frac{12}{2}$. For the subsequent three years, the producer price was keep the same.

In the short run, demand remains relatively price inelastic due to the fact that rice is still culturally the staple food of the Japanese diet. Furthermore, the the short term supply of rice is mostly influenced by the weather conditions, and may not necessarily increase in response to price rises. Therefore, the excess supply does not become so significant even if the price is raised above a market equilibrium. In such a situation, irrespective of how much the producer price would be raised, it would not cause much financial burden to the government if the consumer price were raised in parallel even with a few years' time lag.

In the long run, however, excess supply of rice becomes inevitable as long as the government continue to support the rice price. On the supply side the increased price stimulates the application of fertilizer and other inputs, and in result supply increases. Furthermore on demand side consumers over time gradually substitute towards relatively cheaper, wheat based products such as bread. When the excess supply is created as the result of long-run adjustments in demand and supply to the price support, the resulting extra costs such as storage and surplus disposal can no 
longer be passed on to consumers.

During the $1960 \mathrm{~s}$, average per capita income rose very rapidly, to the extent of doubling in a decade in real terms, and rice consumption declined gradually both absolutely and relative to total household consumption expenditure. The increase in the consumer price of rice was therefore not so strongly resisted and in particular there was no substantial political movements against the increase of rice prices. In the short run, since it was possible to pass on a large part to consumers, the rice price support was raised without too much stress on the treasury. But over the longrun due to the response of the market, it became an increasingly unbearable burden on the government.

It may appear strange to see that the rice price began to be raised again in 1973, as soon as the disposal of surplus rice was completed and the demand-supply equilibrium was restored by the success of the acreage control program 13 . This was partly due to the outbreak of the so-called 'World Food Crisis' of 1973-4. Sharp increases in world food prices, coupled with the U.S. soybean embargo, stirred up anxiety in the public $\underline{14}$. The farm bloc took advantage of this situation in their lobbying for the price increase by advocating greater food self-sufficiency and security.

However, another factor underlying the second surge of rice price support was perhaps that policy makers were slow to predict the market forces creation of a large surplus in response to further price increases. Even if they foresaw this, it might have been difficult for them to present sufficiently strong reasoning to counter the pressure for the price increase. Or it might have been the case that, given the politicians' high rate of discount for future costs and benefits arising from their immediate need for staying in office, it was to their advantage to yield to pressure from the farm bloc.

At any rate, the price support was raised and the acreage control program was relaxed. There followed a repetition of the experience of the 1960s. With increasing excess supply, surplus stock was accumulated and the government deficit escalated, enforcing a price freeze and a strengthening of acreage control in the late 1970s.

The policy-induced cycles thus created have involved a large waste of resources. An obvious example is the accumulation of surplus rice and its disposal at a huge cost. Another example is that the paddy fields (which had been converted from upland fields with large investments for the installation of irrigation systems in response to high prices) were diverted from rice production back to upland crops just when the construction was completed. This suggests that social losses may occur due 
to state intervention, when decisions are made without appropriate consideration of market forces.

\subsection{Emergency rice imports in 1993/94}

Emergency rice imports in 1993/94 in Japan for the first time since some two decades ago, which ironically coincided with the conclusion of the UR, can be understood along the extension of the policy-induced cycle.

When the second surplus was somehow subsided by 1984, the government rice stock began to rise again, partly because production was stimulated by high prices and partly because domestic consumption continued to shrink. A third surplus did emerge in 1987-89 but at a much smaller scale than the previous two incidences, because the government was quick to strengthen acreage control based on experience from the previous failures, with the reduced area amounting to nearly one quarter of the total paddyfield area.

In retrospect, the government became overly cautious about the possibility of another major surplus. The acreage control was maintained at such a high level that the government rice stock was below the normal operational inventory level when the rice crop was severely affected by adverse weather conditions in 1993. (The official rice yield index declining by 26 percent.) Thus, Food Agency had no option but to organize large-scale import activities.

The shortfall of the 1993 rice crop was quickly replaced by a bumper crop in the next year. The 1994 crop was stimulated by both high prices in the previous year (especially in the black market) and relaxation of acreage control. It is likely that by the end of the 1994 rice year (October 1995) the government rice stock will reach a level of 2.5 to 3 million tons, nearly half the level of 1980 which was the peak year of the previous surplus era. Yet, it will not be easy for the government to curtail production for the next few years. Firstly, the reduction in producer prices does not seem politically feasible, because the farm bloc is demanding instead for price hikes as compensation for the acceptance of the UR Agreement. The same applies to acreage control.

A likely course in the short run will be for the government to hold the surplus in stock. The financial constraint on increasing the inventory carryover can be mitigated to some extent by the profit of the Food Agency from the mark-up of minimum-access import rice. Thus, it is not improbable that the government's inventory accumulation will reach the level of the previous two surpluses of the 1970s and 
1980s, and thereafter return to the normal policy mix of high price support and increasing acreage reduction. If so, a large waste of government resources in the form of stock-carrying cost and capital loss from surplus disposal will become inevitable. To that extent, the productive investments, such as agricultural research and extension, that are necessary for the revitalization of agriculture in the post UR regime, will have to be curtailed.

5. A Simulation Analysis

This section shows the economic implications of Japan's postponement of tariffication on rice in contrast to other policy options by means of a simple simulation analysis.

\subsection{Alternative scenarios}

The three options to be compared are:

A. Evade tariffication by increasing minimum-access import quotas gradualy from 4 percent of domestic consumption in 1995 up to 8 percent in 2000; this external commitment is coupled with the domestic policy of strengthening acreage control to reduce rice production by the amount of minimum-access imports so as to maintain the domestic price at the baseline level. The three variants of this scenario after 2000 are:

A-a. Continue to exempt rice from tariffication by increasing minimum access to 12 percent in 2006.

$A-b$. Shift to tariffication in 2001 and thereafter follow the scenario of $B$.

A-c. Shift to tariffication in 2001 and thereafter follow the scenario of $\mathrm{C}$.

B. Start tariffication in 1995 with a pledged reduction in the tariff rate by 15 percent until 2000 and gradually increasing minimum-access import quotas from 3 to 5 percent of domestic consumption within the 6-year period: this external committment is coupled with the domestic policy of strengthening acreage control 
to reduce rice production by the amount of minimum-access imports so as to prevent the domestic price from falling faster than the decrease resulting from the tariff cut; after 2000, the tariff rate will be reduced further by another 15 percent within next six years while minimum-access import will be increased to 7 percent of domestic consumption, which will be counteracted by an equivalent increase in acreage reduction.

C. Start tariffication in 1995 with the same external commitment as Scenario $B$, coupled with the domestic policy of relaxing acreage control by 1 percent per year of total paddyfield area throughout the period until 2006.

In all three scenarios it is assumed that all the losses in producer surplus will be compensated by direct government payments to individual producers in a " decoupled" manner proportional either to their operational landholdings or marketing volumes in the base period. Participants in acreage control programs will also be compensated so as to maintain their welfare position.

Scenario A represents the likely course of the rice sector in Japan since the external commitment explained is the actual situation and the domestic policy considered is the one most likely to be pursued in the medium run, even though in the short run the build-up of government inventory may precede the strengthening of acreage control.

Scenario B would have been the likely course if tariffication were chosen, because, judging from the revealed preference of the government to support domestic producer prices as much as possible within the budgetary constraint, it seems reasonable to expect that the domestic policy will be designed so as to minimize the price decline after tariffication.

In that sense, Scenario $C$ is unrealistic as its policy mix is unlikely to be chosen. It is supposed to represent a policy direction toward the survival and revitalization of Japanese agriculture in the international market.

This simulation analysis traces changes in the domestic price and output of rice as well as government costs, and producers' and consumers' welfare under three alternative policies.

\subsection{Model and parameters}

Our analysis is based on a simple Marshallian partial equilibrium framework 
under a small country assumption. The model of the rice market in Japan is shown in figure 3 with the vertical axis representing price and the horizontal axis representing quantity 15 .

$D_{o}$ represents the domestic demand schedule and $S_{0}$ represents the domestic supply in the absence of acreage control, implying that $a$ is the point of free market equilibrium under autarky. The rice policy in Japan for the past three decades has aimed at raising the domestic price above $a$. The resulting excess supply has been avoided by shifting the supply curve to the left by means of acreage control.

The baseline (pre-market opening) equilibrium is considered to be at point $b$ at which the domestic demand $\left(D_{0}\right)$ and the domestic supply under acreage reduction $\left(S_{l}\right)$ intersect.

If minimum-access import is enforced into this situation and if the imported rice is discharged to the market, the demand for domestic rice will shift from $D_{0}$ to $D_{l}$ with the price lowered to $U$ which corresponds to the equilibrium point $c$. The price can be maintained at $P$, however, if acreage control is strengthened so as to shift domestic supply from $S_{1}$ to $S_{2}$. This is the policy response assumed in Scenario A. In this case there is little need for compensation to producers since their welfare position decreases only slightly, while there is no increase in consumer surplus. The government (Food Agency) gains by area $b d z y$ as the mark-up margin of minimumaccess rice.

If the tariffication is introduced instead, there is no immediate impact on the domestic price because the difference between the domestic price $(P)$ and import price $(W)$ will be levied as a tariff $(t \%$ of $W$ ). Minimum access imports will have the same effect as of Scenario A, although its impact is quantitatively smaller. However, even if acreage control is strengthened so as to shift domestic supply from $S_{1}$ to $S_{2}$ as assumed in Scenario B, the domestic price cannot be maintained at the level of $P$ for long, as the tariff rate will be reduced at the rate of 15 percent over six years. As the initial tariff rate $(t)$ is reduced by $r(\times 100)$ percent, the domestic price is bound to decline from $P$ to $R$ and the import to increase by $e f$ above the minimum-access quota $(f h)$.

In contrast, if acreage control is not strengthened while minimum-access imports are undertaken, the market equilibrium is established at $c$. At this point, if the market price of domestic rice $(U)$ is lower than the price of imported rice after tariff payment $(R)$, as illustrated in figure 3, no additional imports will emerge beyond the minimum access. Scenario $C$ represents the case in which acreage control is relaxed instead of being unchanged. Therefore, the likelihood of no 
additional imports occurring is higher than the case of no changes in acreage control as represented by the equilibrium point $c$. For the sake of diagrammatical presentation simplicity, we represent Scenario $C$ as the case of no change in acreage control.

Gains in consumers' welfare measured by consumer surplus can be calculated by taking integrals of $D_{0}$ with respect to price over the range from $P$ to $R$ for Scenario $\mathrm{B}$ and from $P$ to $U$ for Scenario C. Corresponding changes in producer surplus can be calculated by taking integrals of $S_{2}$ (for Scenario B) and of $S_{1}$ (for Scenario C). For specific computational formulae, see Appendix II.

As for basic parameters, we use 0.4 for the price elasticity of domestic supply and -0.2 for the price elasticity of domestic supply. These are commonly used values for the analysis of the rice market 16 .

For the sake of simplicity we assume the baseline level of domestic consumption before the UR market opening as being 10 million tons of brown rice (which can be converted to milled rice by applying a factor of 0.9 ). The baseline price of domestic rice at the wholesale level is assumed to be 329 yen per $\mathrm{kg}$ of brown rice which is the 1992 average of free market (black market) rice prices based on the survey by the Ministry of Agriculture, Forestry and Fisheries (1994). The baseline difference between the domestic and the import c.i.f. price is assumed to be 4 to 1 , for the reasons discussed in Appendix I.

\subsection{Findings}

Results of the simulation analysis are summarized in table 4 and figure 4 . It must be remembered that the three alternative scenarios for which the simulation analysis is carried out are equivalent in terms of producers' welfare because any welfare loss is supposed to be compensated for by the government payment in a decoupled manner.

Scenario A: No tariffication + Increased minimum access + Increased acreage control

This is the current situation and is likely to continue in the future. According to this scenario, although the domestic price can be maintained at the baseline level, domestic output will continue to shrink. Under the high price support and the strengthened acreage control, no momentum can possibly arise for structural adjustment geared for improving farm efficiency. Possible gains in social welfare from this market-opening scheme will be negligible since consumers receive no benefit 
because of the maintenance of high prices, unless tariffication will be accepted after 2000.

Yet, this is an attractive scenario for the government. The revenue of the Food Agency from the mark-up of minimum-access import rice will amount to nearly 200 billion yen in 2000 and reach as much as 400 billion yen in 2006 if tariffication is avoided after 2000. The increased revenue, with a corresponding expansion in the organization and power of this Agency in the area of rice trading, will be a bonanza for bureaucrats in the Ministry of Agriculture, Forestry and Fisheries. For the Ministry of Finance, which is so concerned about balancing budgets, this scenario is highly attractive because the compensation payment for farmers can be more than fully financed for by the mark-up revenue with no danger of increasing transfers from the general account to the Food Control Special Account under the administration of the Food Agency. It is also attractive for politicians because the maintenance of high prices with the rejection of tariffication can easily be storied as if they are working strongly for the protection of farmers.

Because of the preference of bureaucrats and politicians, it is highly probable that this scenario will continue even after 2000 (Scenario A-a) instead of shifting to tariffication (scenario $A-b$ or $A-C$ ). In short, Scenario A implies the continuation of traditional agricultural policy in Japan geared for charging the cost of agricultural protection to consumers with a minimal burden on the treasury.

\section{Scenario B: Tariffication + Strengthen acreage control}

This would have been the likely situation had tariffication been accepted in the conclusion of UR. In this scenario, the domestic price will decline from the baseline by a modest 11 percent for the first six years, which will result totally from a reduction in the secondary tariff rate, and by another 11 percent for the next six years if the same rate of tariff cut is applied. Corresponding shrinkage in domestic output will be the largest among the three alternative scenarios, by about 10 percent by 2000 and 16 percent by 2006 .

Loss in producer surplus is expected to be large but nearly half of the required income compensation by the government can be financed by the tariff/mark-up revenue from increased imports. Still, the additional budget requirement will amount to about 200 billion yen and 450 billion yen in 2006. Yet social welfare will increase by about 160 billion yen in 2000 and by 300 billion in 2006 . 
Scenario C: Tariffication + Relaxation of acreage control

A very different picture will emerge under tariffication if acreage control is relaxed instead of strengthened. Scenario $C$ will see the largest decline in domestic price but domestic production can be maintained almost at the baseline level right through to 2006. This is because the increased supply of domestic rice will result in a larger price decline than what results from the prescribed tariff cut, and thus the importation of foreign rice will be prevented from increasing above the minimum access quota. The decline in prices, together with greater freedom in land use, is expected to act as an encouragement to structural adjustment for improving farm efficiency. The budget costs of 316 billion yen in 2000 and 514 billion yen in 2006 may appear to be very large but are only modest when compared with the new 6year agricultural support program recently approved, with a budget appropriation of 6 trillion yen as compensation to farmers for the rice market opening due to the UR Agreement. Social welfare gains from this market-opening scheme will be the highest among the three alternatives because of the large gain in consumer surplus.

Yet, for bureaucrats the revenue of the Food Agency from the tariff/mark-up will be small, and thus fall far too short of compensation payments to farmers. In other words, this scenario reduces the consumers' burden of agricultural protection at the expense of the treasury. For this reason, despite its large conribution to the social welfare of the nation as well as encouragement to domestic rice production, this scenario is unlikely to be adopted.

\section{Conclusion}

In general, there is a tendency for agriculture to be protected in highincome countries largely because consumers in affluent economies are tolerant of high food prices. Japan is no exception to this rule. Furthermore, Japan is no exception to the tendency that the lower is a country's comparative advantage in agriculture, the higher is its agricultural protection. This tendency emerges partly because agricultural industries that have declining comparative advantage have to face more serious adjustment problems and, thereby, demand more government assistance. But, an equally or even more important reason appears to be that it is much easier for the importer of agricultural commodities to charge the cost of agricultural protection onto consumers by means of border protection, resulting in less pressure on the treasury. However agricultural protection by the exporter tends to be more constrained because it relies heavily on government expenditure, which can be 
considered as politically costly.

In this perspective the UR agricultural negotiations geared for curtailing agricultural protection are considered to have been undertaken and somehow successfully concluded because EU began to share a common interest with the U.S., in the fact that it has become a major exporter of agricultural commodities since the early 1980s. In contrast, Japan has continued to be a major importer and, hence, has not been subject to such severe pressure from the treasury for reductions in agricultural protection. In the absence of domestic support arising from the point of view of budget saving, Japanese negotiators chose the option of waiting for the other two major players to work out a solution, and then accept the agreement to a minimal extent; this was achieved with the exemption of rice from tariffication.

One could guess that this formula is acceptable at home not because it protects the interests of farmers. Possible negative effects of rice tariffication on domestic agriculture are expected to be very modest by all calculations and, also, can be eliminated altogether if countered by appropriate domestic policies. As suggested by the results in this paper, increased minimum-access import quotas committed for the purpose of compensation could have more adverse effects than tariffication itself. The decision to avoid rice tariffication could be interpreted as a move to protect the vested interests of the Food Agency and agricultural cooperatives who have strong control on rice marketing.

Avoiding tariffication, when coupled with increased acreage reductions equivalent to minimum-access imports, will make it difficult for consumers to enjoy any benefits from the opening of the rice market. But, because it does not require additional budget expenditure, this scheme is likely to meet the approval of the Ministry of Finance and related political circles. This would suggest that the traditional policy mix of supporting producer prices while curtailing domestic production via acreage control, will continue in the future, i.e. Scenario A in our simulation. Under such policy little momentum will emerge for inducing structural adjustments in agriculture in order to close the productivity gap with overseas producers. In contrast, options like Scenario $\mathrm{C}$ in the simulation analysis (i.e. accepting tariffication and relaxing acreage control) are less likely to be adopted due to the opposition from the afore mentioned political groups and the treasury.

Within certain groups it is often said that the international competitive power of Japan's agricultural industry will weaken without certain changes in the government's agricultural policy 17 . However, the evasion of tariffication could imply that the present course will continue at least for the time being. 
Appendix 1. On the Difference between Domestic and Border Prices in Japan

During the autarky with respect to rice ending in 1993 it was difficult to estimate the tariff equivalent for rice because of a sheer absence of border prices. An early attempt to estimate the border price was in the report by the U.S. International Trade Commission (1990). Based a comparison between the average government sale price in Japan and the ex-mill price of medium grain rice in California plus the cost of shipment to Japan, USITC concluded that the tariff equivalent for rice would amount to as high as 600 to 700 percent.

However this USITC calculation is considered to be a gross overestimation partly because quality difference was not considered but more critically because several important cost components such as interest and insurance charges were not counted. The estimates by Y.Hayami after incorporating all the possible marketing costs turned out to range from 200 to 300 percent depending on different assumptions about quality differences (see Forum for Pol icy Innovation (1990)).

The emergency imports that occurred in the 1993 rice year as a result of domestic crop failures produced an opportunity for the evaluation of foreign rice in the Japanese market. Even though this market test could not be so accurate under such a situation, it is still useful information for a broad estimation of the tariff equivalent.

Column 1 in the Appendix Table represents the government sale prices to wholesalers of imported rice from various countries. These prices were determined by the Food Agency when it began to sell the imported rice in November 1993. Relative to the price of Japanese rice, the imported rice of Japonica type from U.S. -California, Australia and China were set prices that were about 20 percent lower, while the prices of Indica rice from U.S. South and Thailand were more than 30 percent lower.

These prices are considered the Food Agency's expectations of the market value of imported rice. Yet, the sale of foreign rice, especially of the Indica type, proved to be slow at these prices despite sharp rises in the price of domestic rice in the free (black) market in the first half of 1994. With the growing expectation that a large stock of foreign rice could be left unsold by the end of the 1993 rice year (actually the stock in October 1994 turned out to be 980 thousand tons, about one third of total import), the Food Agency decided in August 1994 to lower the sale prices of Indica rice and low-quality Japonica rice from China as Indicated in Column 2. 
It is obvious that the initial government sale prices in Column 1 represented overestimates of market-clearing prices of foreign rice in Japan. It is not so obvious if the revised prices in Column 2 were also overestimates under normal market conditions, even though the stock of foreign rice has continued to remain large under these prices. The unusual glut of foreign rice, especially of the Indica type from Thailand, has been created by the Food Agency's scare purchase in a amount far exceeding the absorptive capacity of the Japanese market. If Thai rice had been imported commercially in an appropriate quantity under normal market conditions, its price could have been higher than shown in Column 2. It may not be unreasonable to expect that the market prices of foreign rice at the wholesale level in a normal situation would be somewhere between the initial and the revised prices.

Columns (4) and (5) are obtained by dividing the initial and the revised government sale prices by the import c.i.f. prices, in order to develop a range of estimates on the domestic-border price ratio for rice. The domestic-border price ratios thus calculated are lower than 4 (except that for Chinese rice) before the revision in August 1994.

The c.i.f. prices of $1993 / 94$ in column 3 could have been much higher than normal because of the effect that sudden large-scale purchases by Japan had on the volatile world rice market. On the other hand, in a normal year when the supply of domestic rice is abundant, foreign rice could have only been sold at much lower prices than the government set in this situation. Moreover, to be exactly comparable with the government sale price of domestic rice at the wholesale level, the border prices must include various marketing costs in moving rice from the port to the government warehouse in addition to the c.i.f. price. According to our rough calculation, this additional cost would amount to about 25 yen per $\mathrm{kg}$. To that extent, the domestic-border price ratio in column (4) and (5) may involve a 30 to 50 percent overestimation.

On the other hand, a significant appreciation of the yen has been progressing recently. If the import c.i.f. prices are converted by the current exchange rate, the domestic-border price ratios in column (4) and (5) will increase by 20 to 30 percent.

Considering all such possibilities, it is highly unlikely that the domesticborder price ratio of rice in Japan today (the first half of 1995) would exceed 4 with a tariff equivalent of 300 percent. In our simulation analysis this upper-end estimate is used so as not to underestimate the impact of tariffication on domestic rice market. 
Appendix 2 Formulae for the Simulation Analysis

This appendix specifies formulae used for the simulation analysis whose results are shown in table 4 and figure 4. The demand and supply functions are specified as

$$
\begin{array}{ll}
\text { Demand: } & q_{d}=\gamma p^{-\alpha} \\
\text { Supply: } & q_{s}=\delta A p^{\beta},
\end{array}
$$

where $q_{d}$ and $q_{s}$ are quantities of demand and supply, respectively; $p$ is price; $A$ is area planted in rice; $-\alpha$ and $\beta$ are price elasticities of demand and supply, respectively; $\gamma$ and $\delta$ are constants. While $p$ and $q$ are supposed to be determined at the market equilibrium, $A$ is considered to be exogenous determined by the government acreage control program.

$\alpha$ and $\beta$ are assumed to be 0.2 and 0.4 , respectively. We measure the price and the quantity by the unit of yen per $\mathrm{kg}$ and thousand metric ton both in brown rice terms. Then the baseline (pre-market opening) price and quantity for the Japanese rice market are $p=329$ yen per $\mathrm{kg}, q=10,000$ metric tons, respectively. Normalizing $A$ in the baseline year as $1, \gamma=31,868$ and $\delta=985$.

If all the minimum-access import rice is supplied to the domestic rice market, its price fall drastically. Thus the Japanese government will likely keep some of the minimum-access import rice for several years after the begining of minimum-access import activities, which as stock and/or for foreign aid. We assume that it is only after 1999 that all of the minimum-access imports are supplied to the domestic rice market. Until 1999 the volume of minimum-access imported rice sold in the domestic rice market at year $t$ measured in thousand metric tons $(m)$ is calculated as follows;

$$
\begin{array}{rlrl}
m & =\frac{t-1994}{6} \times 800 & & \text { for Scenario A. } \\
& =\frac{t-1994}{6} \times 500 & \text { for Scenarios B and C. }
\end{array}
$$

In our simulation the cost for accumulation of rice stock and/or foreign aid is abstracted out.

The import price of foreign rice of the same quality as Japanese rice is assumed to be one quater of the baseline domestic price.

The column numbers for respective scenarios indicated below correspond to 
those of Table 4 :

(1)is the solution for $p$ in the equation;

$$
\delta(1-0.01 \times(7)) A p+(6)+m=\gamma p^{-\alpha} \quad \text { for all Scenarios. }
$$

$(2)=100 \times(1) / 329 \quad$ for all Scenarios.

(3) $=\delta(1-0.01 \times(7)) A p^{\beta} \quad$ for all Scenarios.

$(4)=(5)+(6) \quad$ for all scenarios.

$(5)=400+(800-400) \times(t-1995) / 5$ for $t=1995 \sim 2000$ for Scenario A.

$=800+(1,200-800) \times(t-2006) / 6$ for $t=2000 \sim 2006$ for Scenario A-a.

$=800+(1,000-800) \times(t-2006) / 6$ for $t=2000 \sim 2006$ for Scenarios A-b and A-c.

$=300+(500-300) \times(t-1995) / 5$ for $t=1995 \sim 2000$ for Scenarios $B$ and $C$.

$=500+(700-500) \times(t-2006) / 6$ for $t=2000 \sim 2006$ for Scenarios B and C.

$(6)=0$ for $t=1995 \sim 2000$ for Scenario $A$.

$=0$ for $t=2000 \sim 2006$ for Scenario $A-a$.

$=\max .\left[0, \gamma \eta^{-\alpha}-\delta(1-0.01 \times(7)) A \eta^{\beta}-(5)\right]$

for $t=2000 \sim 2006$ for Scenarios $A-b$ and $A-c$.

$=\max .\left[0, \gamma \eta^{-\alpha}-\delta(1-0.01 \times(7)) A \eta^{\beta}-(5)\right] \quad$ Scenarios B and C.

where

$$
\eta=329 \times\left\{1+3\left(1-\frac{t-1994}{6} \times 0.15\right)\right\}
$$

which is the import price of rice including tariff. Strictly speaking, tariff rate decreases exponentially according to the UR Agreement. But we approximate it by liner function for simplification.

(7) $=m / 10,000$ for $t=1995 \sim 2000$ for Scenarios $\mathrm{A}$ and $\mathrm{B}$.

$=(5) / 10,000 \quad t=2000 \sim 2006$ for Scenarios $A-a, A-b$ and $B$.

$=800 / 10,000-(t-2000)$ for $t=2000 \sim 2006$ for Scenarios A-c.

$=-(t-1994)$ for $t=1995 \sim 2006$ for Scenarios $C$.

$(8)=0.001 \times((6)+m) \times((1)-329 / 4) \quad$ Scenarios B and C. 
$(9)=0.001 \times((1) \times(3)-329 \times 10,000) /(1+\beta) \quad$ for all Scenarios.

$(10)=0.001 \times \int_{(1)}^{329} \not p^{-\alpha} d p \quad$ for all Scenarios.

The reason of multiplying by 0.001 in equations (8), (9) and (10) is to express in unit of billion yen.

$(11)=(8)+(9) \quad$ for all Scenarios.

$(12)=(8)+(9)+(10) \quad$ for all Scenarios. 
Footnotes

1. The Japanese government prohibited rice imports during the last quarter century with a few notable exceptions. This import prohibition has been occationally criticized as a violation of GATT rules at international talks. To take an outstanding example, the RMA (the Rice Millers' Association of the U.S.) filed complaints under Section 301 of the Trade Act calling for the opening of the Japanese rice market in 1986 and 1988. The USTR (the United States Trade Representative) substancially dismissed the claims by the RMA, presupposing that the rice issue would be resolved at the UR negotiations. Although there was substantial pressure on the rice market, the Japanese Diet adopted resolutions reqiring the government to firmly maintain rice imports prohibition in 1980, 1984 and 1988.

2. The ratio of gross value added to output value in rice is estimated to be a little less than $70 \%$, using the annual surveys by the Japanese Ministry of Agriculture, Forestry and Fisheries on rice production cost (Kome Seisanhi Chosa). The sample of farmers in this survey is said to be biased towards high-yield farmers and the profitability of rice exceeds the average level of other agricultural products. If we consider these points, the real ratio of gross value added in Japanese agriculture may be below $60 \%$ of the total output value. Thus, the estimation of the value added of Japanese agriculture in the text is somewhat overestimated. Nevertheless, it is concluded that GDP would increase without agricultural sector.

3. Such relations are also confirmed by econometric analysis in: Honnma and Hayami (1986a), (1986b), (1991).

4. For more detail, see International Agricultural Trade Research Consortium (1994), pp.46-51.

5. For more detail, see Hayami (1988), Chapters 1 and 3.

6. See International Agricultural Trade Research Consortium (1994) pp.40-46. Under the UR agreement the Food Agency of Japan is allowed to mark up the price of minimum access import rice to as high as 332 yen per $\mathrm{kg}$ which is 8 
times higher than the border price of Thai rice. Therefore, it is likely that, if Japan were to have accepted tariffication, the tariff rate of 700 percent would have applied to rice. This rate is far higher than the real tariff equivalent, as discussed in Appendix I.

7. The Japanese government imposed quotas on beef imports before 1990. The Livestock Industry Promotion Corporation ( Chikusan Shinko Jigyodan), which is an extra-departmental organization of the Japanese Ministry of Agriculture, Forestry and Fisheries, controlled beef imports. Beef as well as orange have been treated as symbols of the closeness of Japanese market in the US - Japan trade talks, which heated up especially in the 1980's. The Japanese government withstood increasing import quotas at first but finally agreed to undertake beef tariffication (beginning in 1991) in 1988.

8. As for the influences for beef tariffication on domestic beef production, see Mori and Gorman (1995).

9. Corresponding to the acceptance of the UR Agreement, the government enacted in 1994 a so-called New Food Law for the replacement of the Food Control Law. (The new Law comes into force on the 1st of November, 1995.) Similar to the old Law, the new Law is very general and abstract so that it is hard to judge how the rice distribution system will be changed. The future depends much on ministerial orders and administrative guidance.

10. See Hayami (1988), Chapters 3 and 6.

11. This section draw heavily on Hayami (1988), Chapter 3 Section 2.

12. The first diposal of surplus rice occured in 1971-74 with government expenditure reaching 1 trillion yen (As for the second instance, see note 13). About 7.4 million metric tons are exported at low prices or crushed and used for feed or food processing.

13. The second disposal of surplus rice occurred in 1979-86. The volume was about 6 million metric tons and was exported or sold for feed or food processing just the same way as the first disposal. In this instance, the 
government expenditure was 2 trillion yen.

14. In the World Food Crisis, the USA invoked a soybean embargo from June 27th to September 8th in 1973 as a measure to counter inflation. As Japan is a major soybean importer, this created considerable turmoil and placed pressure on food prices.

15. The model used here represents a revision of the model developed by $Y$. Hayami and K. Otuska in Forum for Policy Innovation (1993).

16. See Otsuka and Hayami (1985).

17. For details, see Forum for Policy Innovation (1990), (1993) and Godo (1994). 


\section{References}

Forum for Policy Innovation. 1990. Toward Tariffication for Opening the Rice Market in Japan, Tokyo.

Forum for Policy Innovation. 1993. Kome Shijo Kaiho to Zaisei Futan ( Rice Market Opening and Fiscal Burden), Tokyo.

Godo, Y., 1994. Nochi Kisei Nochi Zeisei no Mondaiten to Kaizenhoko ( Problems and Policies of Farmland Regurations and Taxation), Tokyo: Forum for Policy Innovation.

Godo, Y., and L. Owens. 1995. An Estimation of the Border Price Ratio of Rice in Japan, mimeo.

Hayami, Y. 1988. Japanese Agriculture under Siege, London: McMillan.

Honnma, M., and Y. Hayami. 1986a. "Structure of Agricultural Protection in Industrial Countries, "Journal of International Economies, 20, pp.115-29

Honnma, M., and Y. Hayami. 1986b. "The determinants of Agricultural Protection Levels: An Econometric Analysis ," in K. Anderson and Y. Hayami, eds. The Political Economy of Agricultural Protection, Sydney: Allen and Unwin, pp.39-49.

Honnma, M., and Y. Hayami. 1991. "Causes of Growth in Agricultural Protection," in Y. Hayami and S. Yamada, eds., The Agricultural Development of Japan, Tokyo: University of Tokyo Press, pp.221-39.

International Agricultural Trade Research Consortium. 1994. The Uruguay Round Agreement on Agriculture: An Evaluation, IATRC Commissioned Paper No.9.

International Trade Commission. 1990. Estimated Tariff Equivalents of Nontariff Barriers on Certain Agricultural Imports in European Community Japan and Canada, Washington D.C..

Japan Ministry of Agriculture. 1994. Statistics and Information Department, Forestry and Fisheries, Statistics of Price and Wages in Rural Area (Noson Bukka Chinnginn Tokei), Tokyo.

Mori, H., and W. D. Gorman . 1985. "The Japanese Beef Market Following Liberalization: What Has and Has Not Happened?," Journal of Rural Economics 67(1), pp.20-30

Otsuka, K., and Y. Hayami. 1985. "Goals and Consequences of Rice Policy in Japan, 1965-80," American Journal of Agricultural Economics 67, pp.529-38 
Table 1. Producer subsidies and consumer burdens by agricultural protection policies in selected economies, 1991-93

\begin{tabular}{|c|c|c|c|c|}
\hline & \multirow{3}{*}{ PSE/Ag. Output } & (2) & (3) & (4) \\
\hline & & \multirow[t]{2}{*}{$(-\mathrm{CSE}) / \mathrm{PSE}$} & \multicolumn{2}{|c|}{$\begin{array}{c}\text { Grain self-sufficiency } \\
\text { rate }(\%)\end{array}$} \\
\hline & & & $1974-76$ & $1984-86$ \\
\hline $\begin{array}{l}\text { Japan } \\
\text { (Rice) }\end{array}$ & $\begin{array}{l}69 \\
(\quad 92)\end{array}$ & $\left(\begin{array}{r}112 \\
97\end{array}\right)$ & 40 & 33 \\
\hline EU & 48 & 74 & 86 & 114 \\
\hline U. S. A. & 22 & 45 & 157 & 159 \\
\hline Australia & 10 & 29 & 348 & 426 \\
\hline
\end{tabular}

Note. PSE : producer subsidy equivalents CSE : consumer subsidy equivalents

Grain self-sufficiency rate: total grain output/total grain consumption

Source. OECD Agricultural Policies, Harket and Trade; Food Consumption Statistics 1985,1991 
Table 2 Imports of beef to Japan, 1985-94

$\left.\begin{array}{cccc}\hline \text { year } & \begin{array}{c}\text { Tariff } \\ \text { rate } \\ (\%)\end{array} & \begin{array}{c}\text { Import quantity } \\ \text { ('000 metric ton) }\end{array} & \begin{array}{c}\text { Rate of increase } \\ \text { from previous year } \\ (\%)\end{array} \\ 1985 & & 150.6 & \\ 1986 & & 179.1 & 18.9 \\ 1987 & & 220.0 & 22.9 \\ 1988 & & 263.5 & 19.8 \\ 1989 & & 348.7 & 32.8 \\ 1990 & & 376.1 & 7.9 \\ 1991 & 70 & 353.1 & -6.1 \\ 1992 & 60 & 411.6 & 16.5 \\ 1993 & 50 & 511.6 & 24.3 \\ 1994 & 50 & 588.6 & 15.1\end{array}\right\}$ Av. 20.4

Source: Japan Ministry of Agriculture, Forestry and Fisheries, Monthly Statistics of Agriculture Forestry and Fisheries 
Table 3. Illustration of the safeguard measures

\begin{tabular}{|c|c|c|c|c|c|c|}
\hline & \multicolumn{3}{|c|}{ Ad valorem tariff } & \multicolumn{3}{|c|}{ Specific duty } \\
\hline & No safeguard & $\begin{array}{l}\text { Price-trigger } \\
\text { safeguard }\end{array}$ & $\begin{array}{l}\text { Quantity-trigger } \\
\text { safeguard }\end{array}$ & No safeguard & $\begin{array}{l}\text { Price-trigger } \\
\text { safeguard }\end{array}$ & $\begin{array}{l}\text { Quantity-trigger } \\
\text { safeguard }\end{array}$ \\
\hline Border price & \multicolumn{2}{|c|}{50 yen $/ \mathrm{kg}$} & & \multicolumn{2}{|c|}{50 yen $/ \mathrm{kg}$} & \\
\hline Tariff $(300 \%)$ & \multicolumn{2}{|l|}{150} & & \multicolumn{2}{|l|}{150} & \\
\hline $\begin{array}{c}\text { Domestic price(A) } \\
\checkmark\end{array}$ & \multicolumn{2}{|l|}{200} & & 200 & & \\
\hline Border price & 10 & 10 & 10 & 10 & 10 & 10 \\
\hline Tariff $(300 \%)$ & 30 & $46^{a}$ & $39^{b}$ & 150 & $166^{\mathrm{a}}$ & $195^{\mathrm{c}}$ \\
\hline Domestic price(B) & 40 & 56 & 79 & 160 & 176 & 205 \\
\hline $\begin{array}{l}\text { Rate of domestic } \\
\text { price decrease }(\%) \\
\qquad(B-A) / A\end{array}$ & -80 & -72 & -40 & -20 & -12 & 3 \\
\hline
\end{tabular}

a. Initial tariff plus $16.4 \mathrm{yen} / \mathrm{kg}: 16.4=\frac{5 \times 0}{10 \%}+\frac{(20-5)}{10 \sim 40 \%} \times \frac{0.3}{40 \sim 60 \%}+\frac{(30-20)}{40.5}+\frac{(37-30)}{60 \sim 75 \%} \times 0.6+\frac{(40-37)}{\text { above }} \times 0.9$

b. $30 \times 1.3 \quad$ c. $150 \times 1.3$ (Increase in the tariff rate by 30 percent when import quantity increases by 26 percent from the previous three-year average)

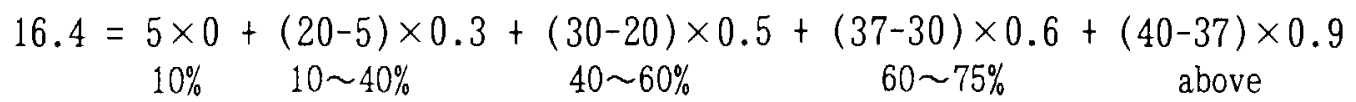


Table 4 Results of the simulation analysis

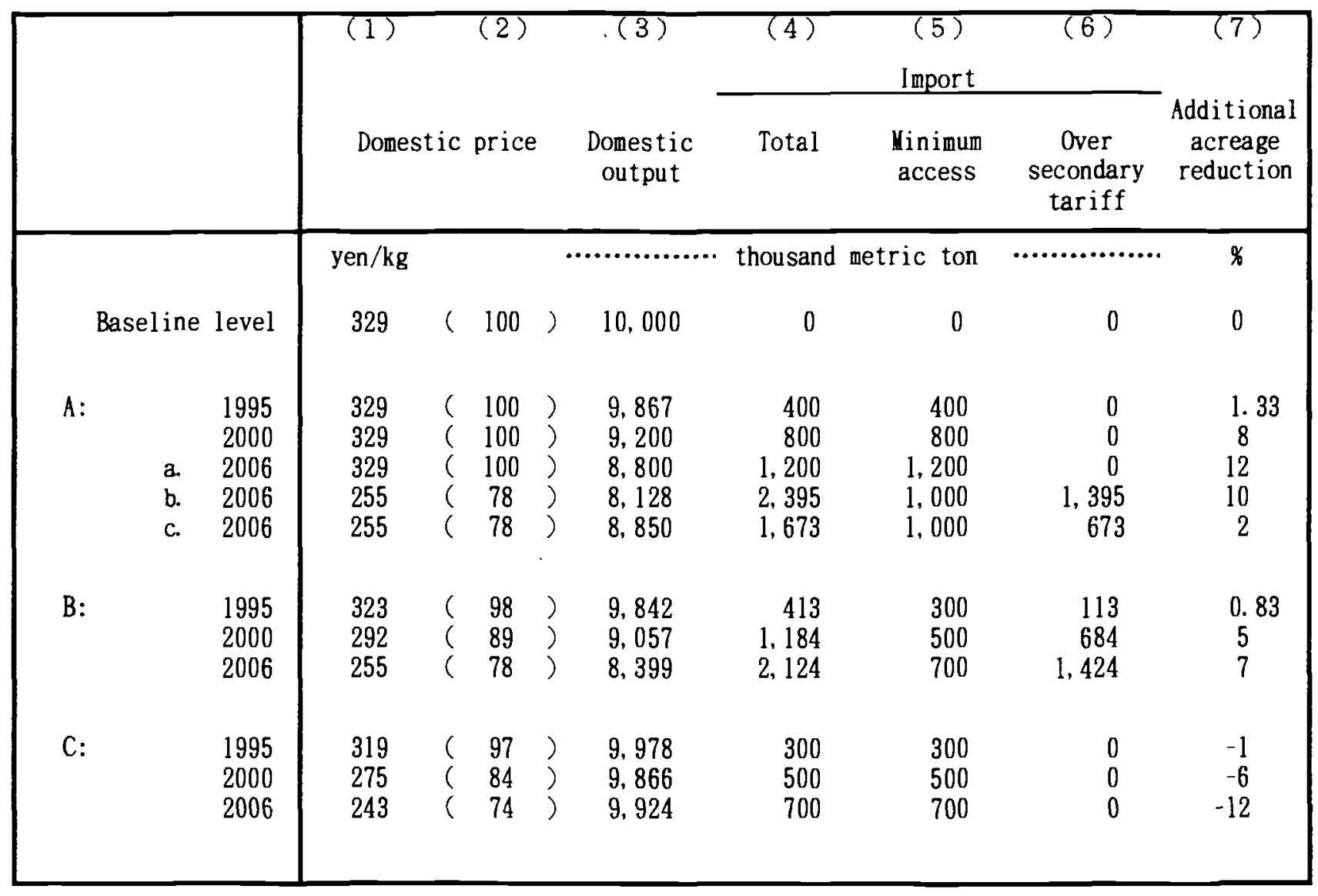

A: No tariffication with increased minimum access import + Equivalent increase in acreage reduction:

A-a : Continue the same policy after 2000

$\mathrm{A}-\mathrm{b}:$ : Shift to tariffication after $2000+$ Increase acreage reduction

A-c : Shift to tariffication after $2000+$ Decrease acreage reduction

B: Tariffication + Increase acreage reduction equivalent to minimum access import

C: Tariffication + Decrease acreage reduction by one percent per year of total paddyfield area 
Table 4 (continued)

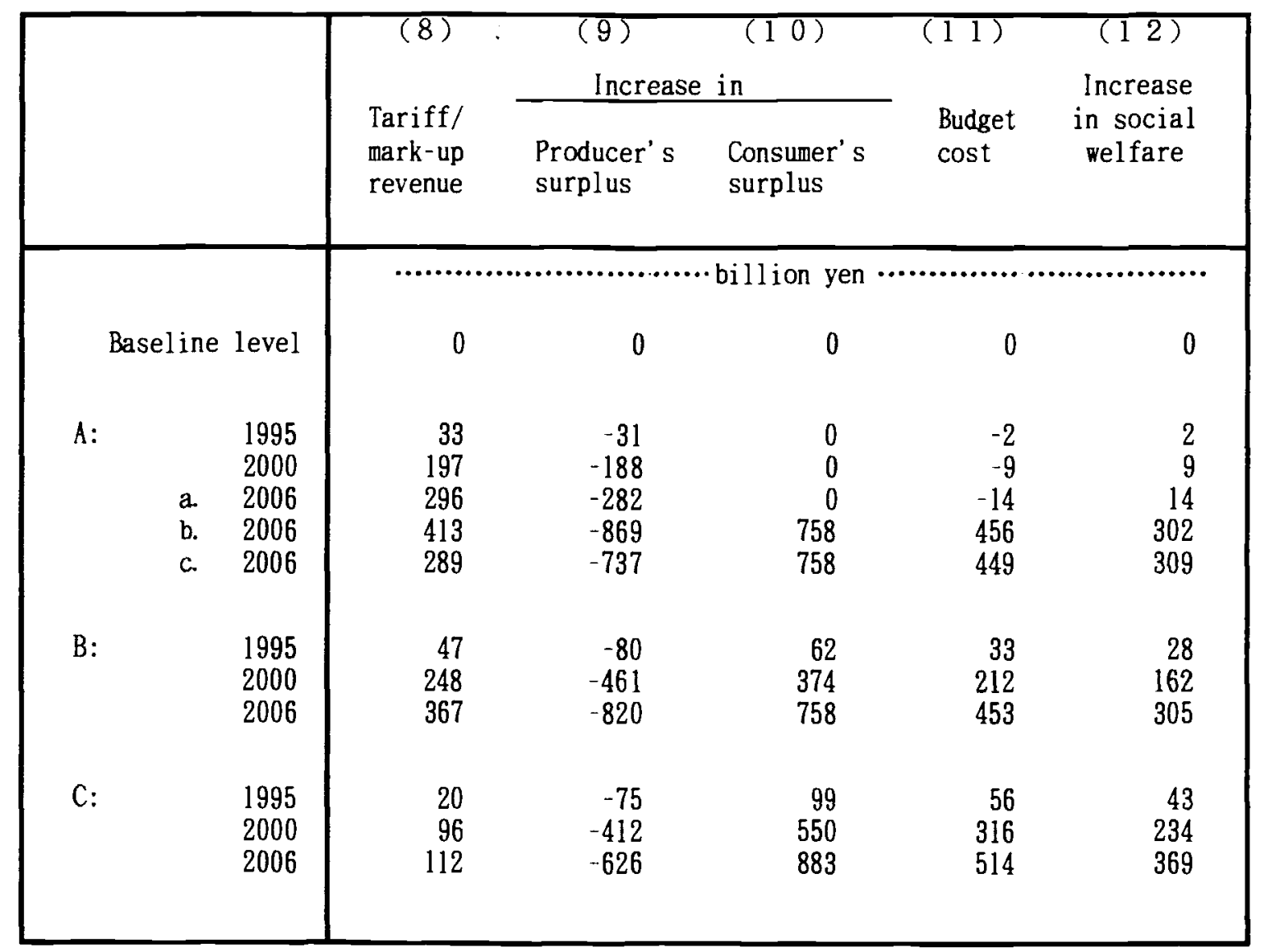

$\Lambda$ : No tariffication with increased minimum access import + Equivalent increase in acreage reduction: A-a : Continue the same policy after 2000

A-b : Shift to tariffication after $2000+$ Increase acreage reduction

A-c : Shift to tariffication after $2000+$ Decrease acreage reduction

B: Tariffication + Increase acreage reduction equivalent to minimum access import

C: Tariffication + Decrease acreage reduction by one percent per year of total paddyfield area 
Appendix Table Comparisons between government sale prices and import cif price of foreign rice in the 1993 rice year (November 1993-October 1994)

\begin{tabular}{|c|c|c|c|c|c|}
\hline \multirow[b]{2}{*}{ Country } & (1) & $(2)$ & \multirow{3}{*}{$\begin{array}{c}\text { (3) } \\
\text { Import } \\
\text { cif price }\end{array}$} & \multirow{3}{*}{$\begin{array}{c}(4) \\
=(1) /(3)\end{array}$} & \multirow{3}{*}{$\begin{aligned} & (5) \\
= & (2) /(3)\end{aligned}$} \\
\hline & \multicolumn{2}{|c|}{ Govenment sale price } & & & \\
\hline origin & Initial ${ }^{a}$ & Revised ${ }^{b}$ & & & \\
\hline & $\ldots \ldots \ldots \ldots \ldots \ldots, y_{1}$ & of brown rice .. & .............. & & \\
\hline Japan & $302.1^{d}(100)$ & $302.1^{d}(100)$ & --- & --- & --- \\
\hline U.S.A. & & & 65.9 & & \\
\hline Cal ifornia & $236.5(78)$ & $240.7(80)$ & & 3. $6^{\mathrm{e}}$ & $3.7^{\mathrm{e}}$ \\
\hline South & $208.9(69)$ & $137.9(46)$ & & $3.2^{e}$ & $2.1^{e}$ \\
\hline Australia & $223.1(74)$ & $242.6(80)$ & 71.3 & 3. 1 & 3.4 \\
\hline China & & & 52.8 & & \\
\hline Dongbe & $205.6(68)$ & $128.1(42)$ & & 3. $9 \mathrm{f}$ & $2.4 \mathrm{f}$ \\
\hline Xiaozham & $218.6(72)$ & $144.3(48)$ & & $4.1 \mathrm{f}$ & $2.7 \mathrm{f}$ \\
\hline Changshu & $213.6(71)$ & $128.1(42)$ & & $4.0^{f}$ & $2.4 \mathrm{f}$ \\
\hline Thailand & $199.9 \&(66)$ & $106.58(35)$ & $55.6 \mathrm{~g}$ & 3.6 & 1.9 \\
\hline
\end{tabular}

a Effective before 26th August 1994

b Effective after 26th August 1994

c Average for November 1993 - October 1994

d Average for government rice, grades No. 1-5

e Divided by the average cif price for U.S. A.

f Divided by the average cif price for China

$g$ Price in milled rice

Source: Govenment sale price: announced by the Food Agency

Import cif price: Customs Bureau, Japan Ministry of Finance, Nihon Boeki Geppyou ( Japan Exports \& Imports ), various issues. 


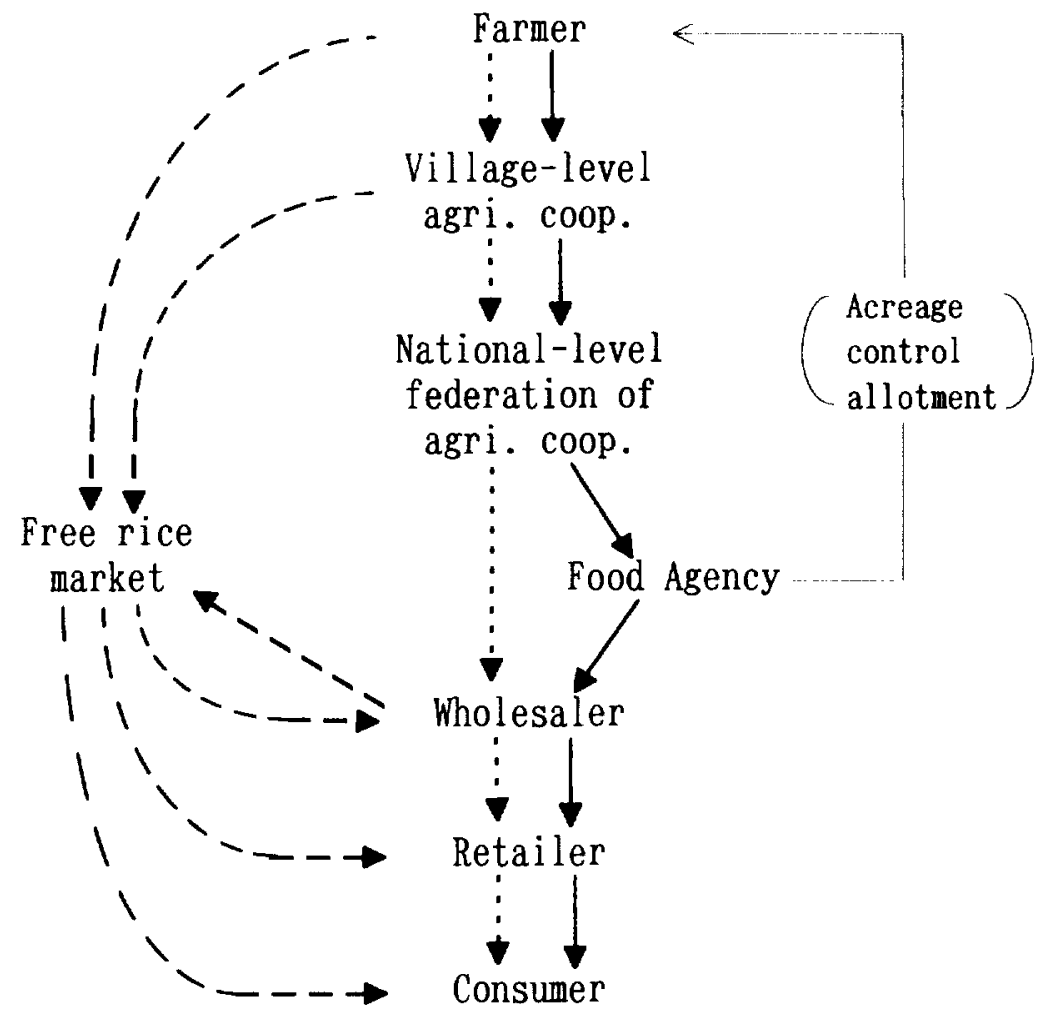

$\begin{array}{lll}\text { Jiyu Mai } & \text { Jishu Ryutsu Mai } & \text { (volantary rice) }\end{array} \quad \begin{aligned} & \text { Seifu Mai } \\ & \text { (government rice) }\end{aligned}$

Note: Wholesalers and retailers are licensed by region

Figure 1. The system of rice marketing under the Food Control Law 


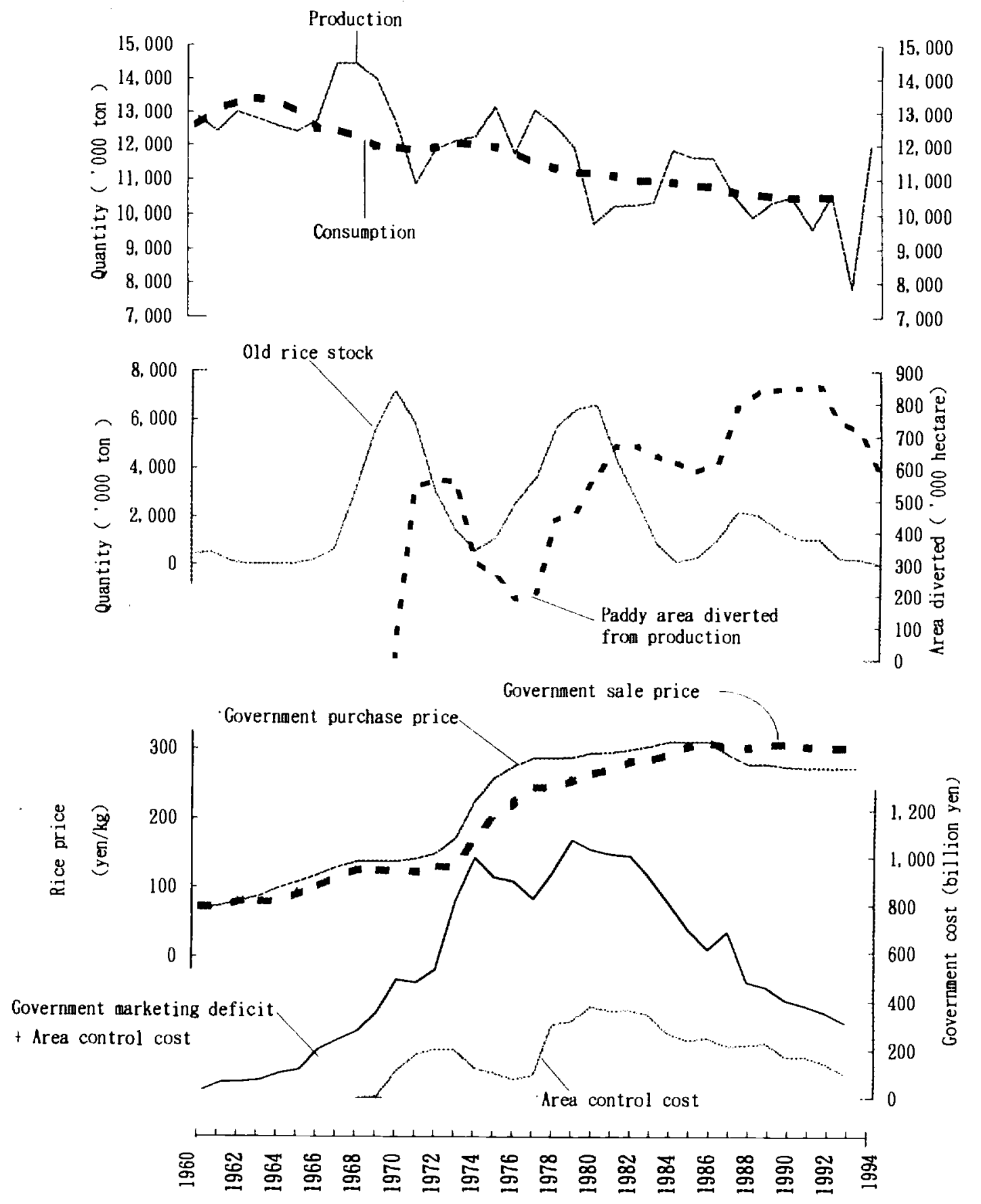

Figure 2 Policy-induced cycles in the rice market

Source: Japan Vinistry of Agricul ture, Forestry and Fisheries (JUAFF), Shokuryo Kanri Tokei Nenpo (Annual Report of Food Control Statistics); Norin Suisan Sho Tokeihyo (Statistical Yearbook of JMAFF); Shokuryo Jikyu Hyo (Food Balance Sheets); Nogyo Hakusho Fuzoku Tokei Hyo (Statistical Appendix to the Agricul tural White Paper) 


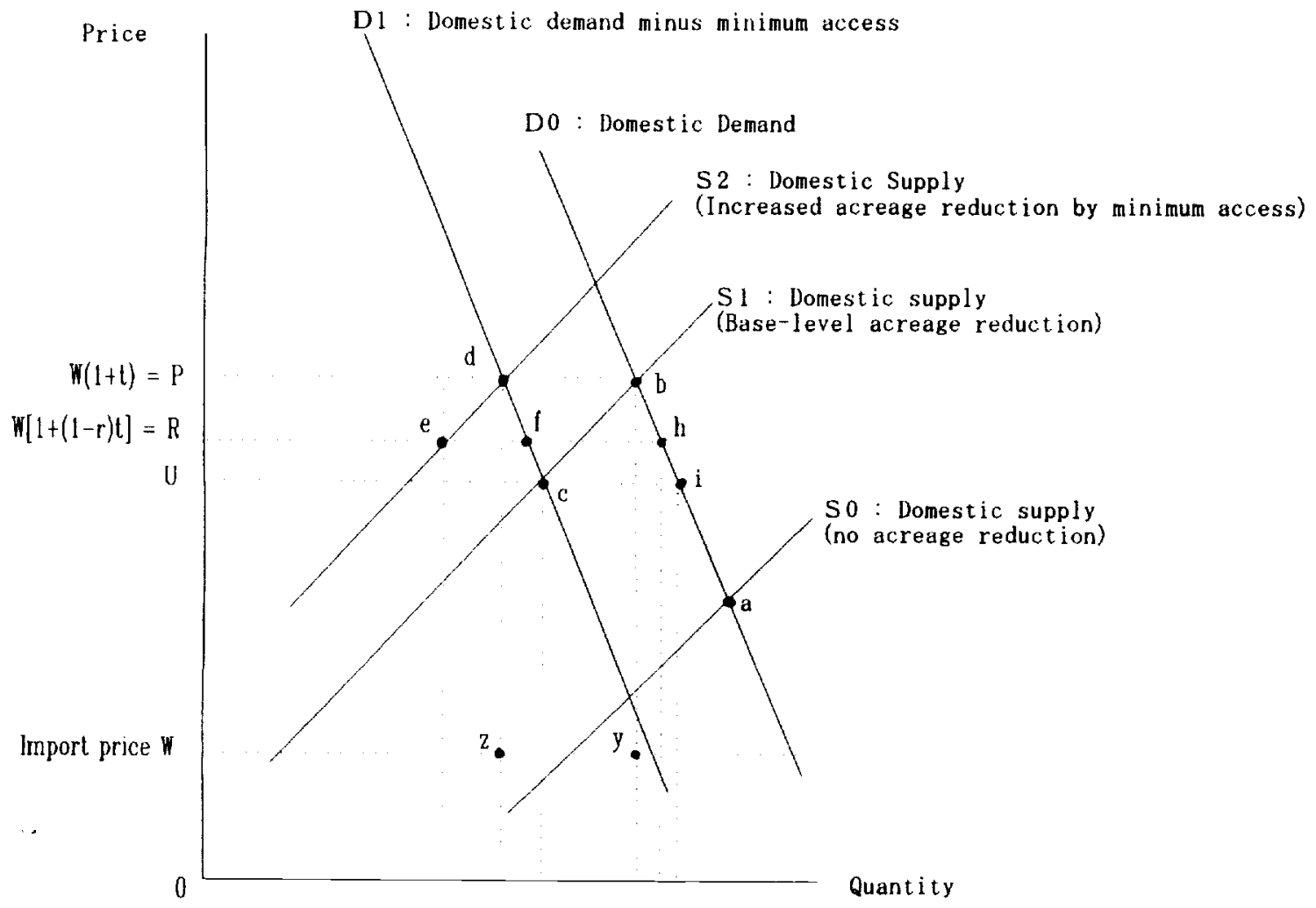

Figure 3 Effects of rice market opening in Japan 
i. Domestic rice price (1)

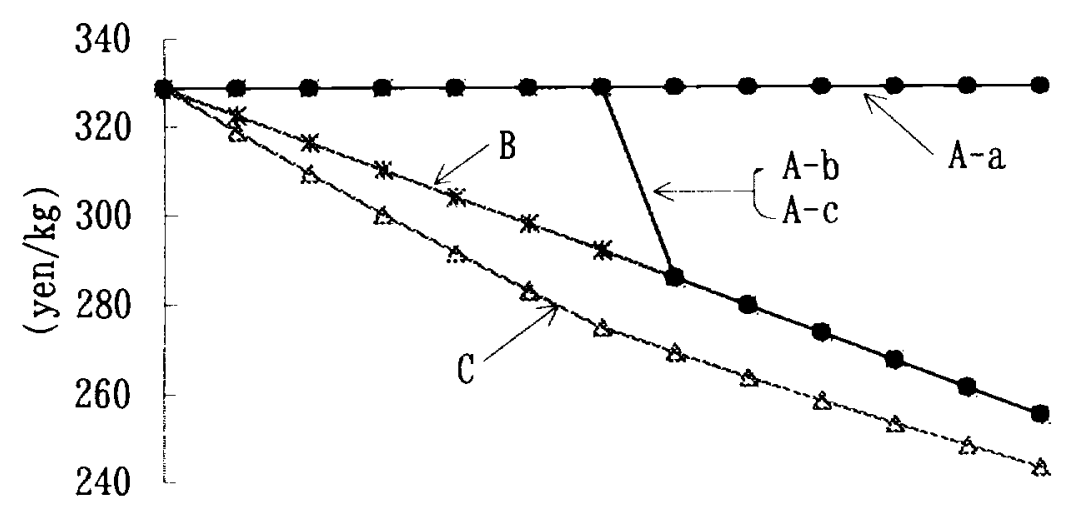

ii. Domestic rice output(3)

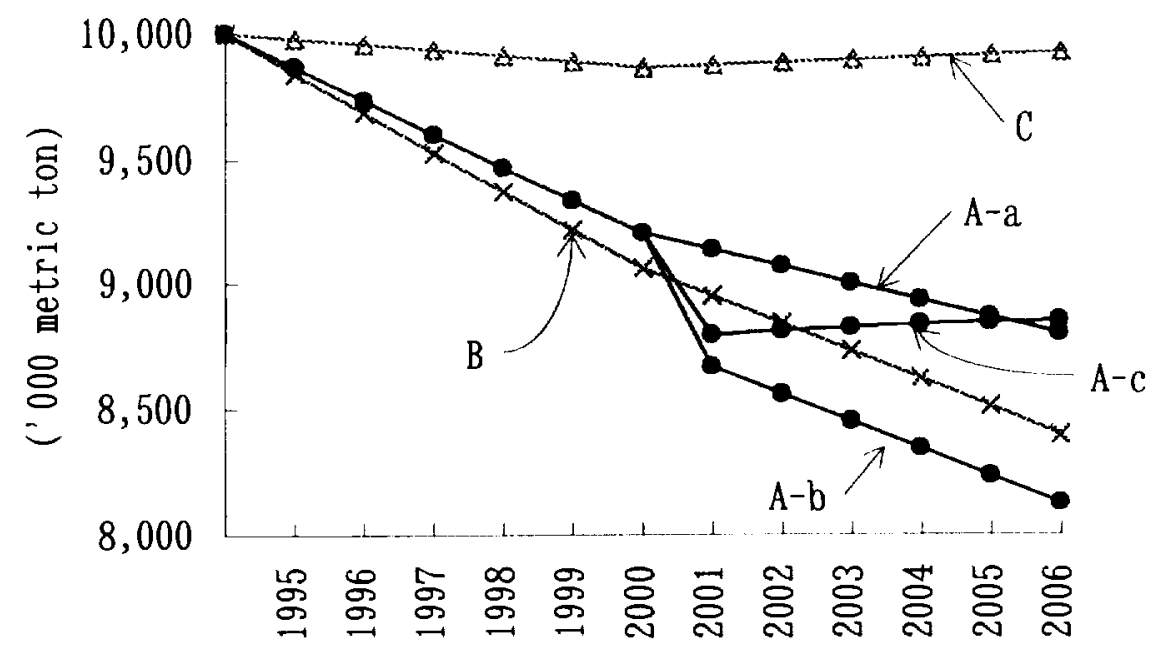

Figure 4 Result of the simulation analysis

Note : Numbers in parenthesis correspond to column number in Table 4 Scenario A : No tariffication + Increased minimum access + Increased acreage control A-a : Continuing above policy mix even after 2000

$A-b$ : Shifting to tariffication with strengthening acreage control after 2000

$A-C$ : Shifting to tariffication with relaxing acreage control after 2000

Scenario B : Tariffication + Strengthen acreage control

Scenario C : Tariffication + Relax acreage control 
iii. Additional budget cost (11)

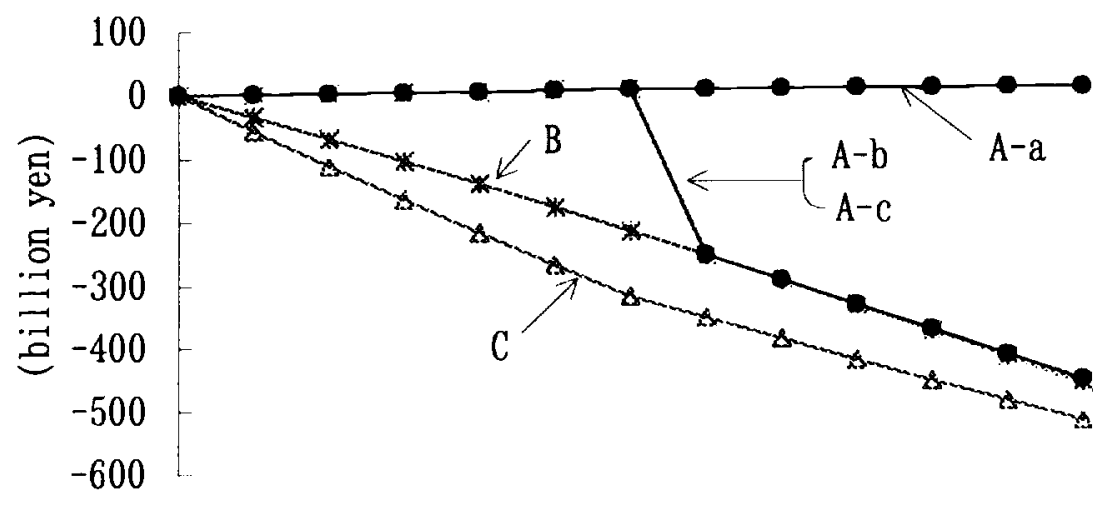

iv. Increase in social welfare (12)

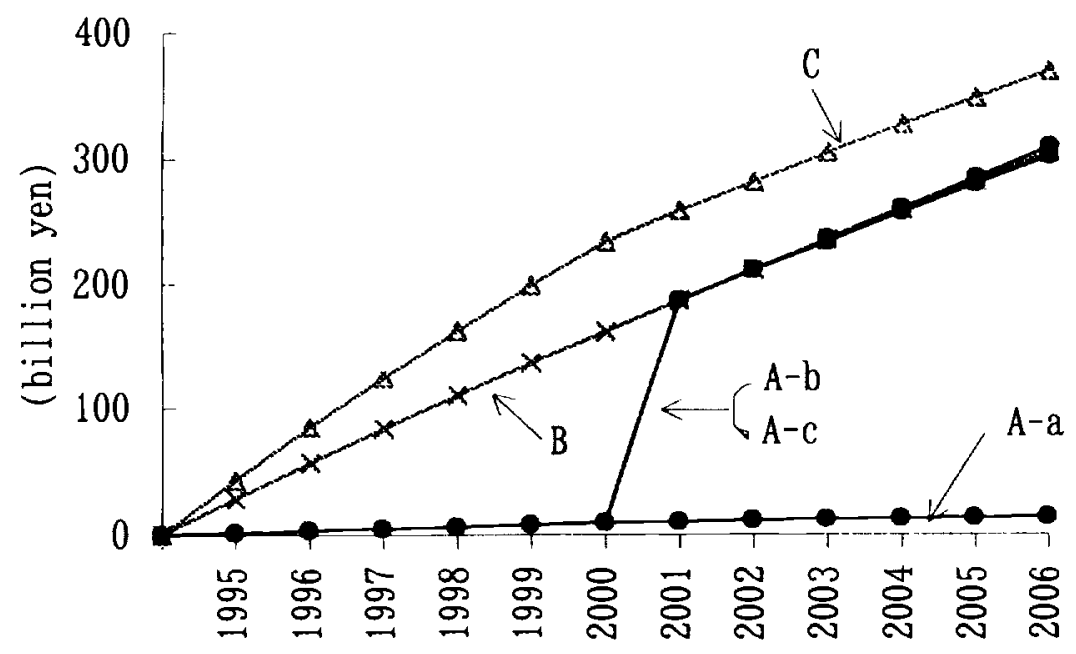

Figure 4 Result of the simulation analysis (continued) 